Удк: 338.43:633.11(470)

\title{
ТЕНДЕНЦИИ И СТРУКТУРНЫЕ СДВИГИ В ФОРМИРОВАНИИ ПРЕДЛОЖЕНИЯ НА ЗЕРНОВОМ РЫНКЕ РОССИИ
}

\author{
С.Н. Широков к.э.н., И.Р. Трушкина к.б.н. \\ Санкт-Петербургский государственный аграрный университет
}

В.С. Алексанян к.э.н.

Национальный аграрный университет Армении

shirokovspbgau@mail.ru, auriairina@mail.ru, vardan.aleqsanyan@gmail.com

\section{СВЕДЕНИЯ}

Ключевые слова:

зерно,

валовой продукт,

кривая Лоренца,

рынок зерна,

Российская Федерация

\begin{abstract}
АННОТАЦИЯ
Изучение вопросов формирования предложения на зерновом рынке Российской Федерации через показатели валового сбора зерновых и зернобобовых культур, взятые в качестве соответствующих индикаторов, позволяет выявить тенденции и структурные сдвиги в формировании предложения на зерновом рынке.
\end{abstract}

На основе проведенных исследований можно судить как о результативности предпринимаемых на протяжении последних лет активных мер со стороны государства и бизнеса по увеличению объемов производства зерновых, так и о необходимости решения комплекса неотложных задач по обеспечению устойчивости в подсистеме рынка зерна со стороны предложения, включая, в первую очередь, реализацию потенциала пока отстающих регионов.

\section{Введение}

В системе организации национального, региональных и местных агропродовольственных рынков большая роль отводится рынку зерна. Он влияет на функционирование других видов рынков и достижение сбалансированного состояния национальной продовольственной системы в целом. Производство зерновых лежит не только в основе продовольственного рынка России, но и является одной из важнейших подсистем рынка зерна.

Растущий уровень конкуренции на мировом рынке зерна и продуктов его переработки, а также другие глобальные факторы вызывают необходимость постоянного изучения причинно-следственных взаимосвязей в функционировании зернового комплекса. Трудности с получением для этого объективных эмпирических данных значительно усложняют задачу исследования и вызывают потребность в использовании индикаторов на основе косвенных показателей. Поэтому рассмотрим вопросы формирования предложения на зерновом рынке Российской Федерации через показатели валового сбора зерновых и зернобобовых культур, взятые в качестве соответствующих индикаторов. Тенденции и структурные сдвиги в формировании предложения на зерновом рынке в этом случае могут быть установлены на основе использования доступной официальной статистической информации, что позволяет осуществить их определенную экстраполяцию на перспективу. 


\section{Материалы и методы}

Теоретическую и методологическую основу исследования составили работы российских и зарубежных авторов по проблемам обеспечения продовольствием населения и развития зернового подкомплекса. Информационной базой являлись государственные и ведомственные нормативные акты, материалы Федеральной службы государственной статистики Российской Федерации. В ходе исследований были использованы методы анализа и синтеза, абстрактно-логический и экономико-статистический, с применением В качестве технических средств программных продуктов Microsoft Office, что позволило более комплексно представить связанные со сферой проблемы и меры, направленные на их выявление.

\section{Результаты и анализ}

Проведенный анализ динамики валового сбора зерновых и зернобобовых культур с начала реализации Приоритетного национального проекта «Развитие АПК» 2006-2007 гг. (Н.П. Воронина, 2019) по настоящее время показывает, что в целом по Российской Федерации его объемы в 2016-2020 гг., относительно 2006-2010 гг., во всех категориях хозяйств выросли на 46,5 \%, в том числе за счет пшеницы (50 \%), кукурузы (224\%), гречихи (44 \%), риса (31\%), ячменя (17\%), тритикале (185\%), сорго (256 \%). При этом сократились объемы производства ржи, овса и проса, соответственно, на 37,6; 4,9; 5,9 процента.

Рост объемов валового сбора зерновых и зернобобовых культур мог обеспечиваться одним из таких факторов как повышение спроса на отдельные виды зерна. Однако, несмотря на высокие темпы прироста объемов производства сорго, тритикале, риса и гречихи, их доля в структуре валового сбора зерновых и зернобобовых культур (каждого в отдельности в среднегодовом исчислении в 2016-2020 гг. ) составляла менее одного процента.

Зерновой баланс в годы рассматриваемой пятилетки, главным образом, состоял на 62,8 \% из пшеницы, $15,5 \%$ - ячменя, 10,9 \% - кукурузы, суммарная доля которых достигла 89,2 \% общего валового сбора зерновых и зернобобовых культур. При этом следует отметить, что среди остальных видов зерна в структуре его производства выделяются заметно низким удельным весом рожь - 1,7 \%, зернобобовые - 2,8 \% и овес - 3,8\%.

Рост объемов производства зерна был вызван не только повышением внутреннего спроса на него, но и увеличением экспортных поставок к 2020 г. до 57,5 млн. т, в том числе пшеницы до 38,3 , ячменя - до 6,1 и кукурузы - до 3,7 млн. тонн. Из произведенных в стране для реализации на зарубежные рынки фактически поставлялось 44,6 \% объема пшеницы, 29,2 \% ячменя, 26,6 \% кукурузы.

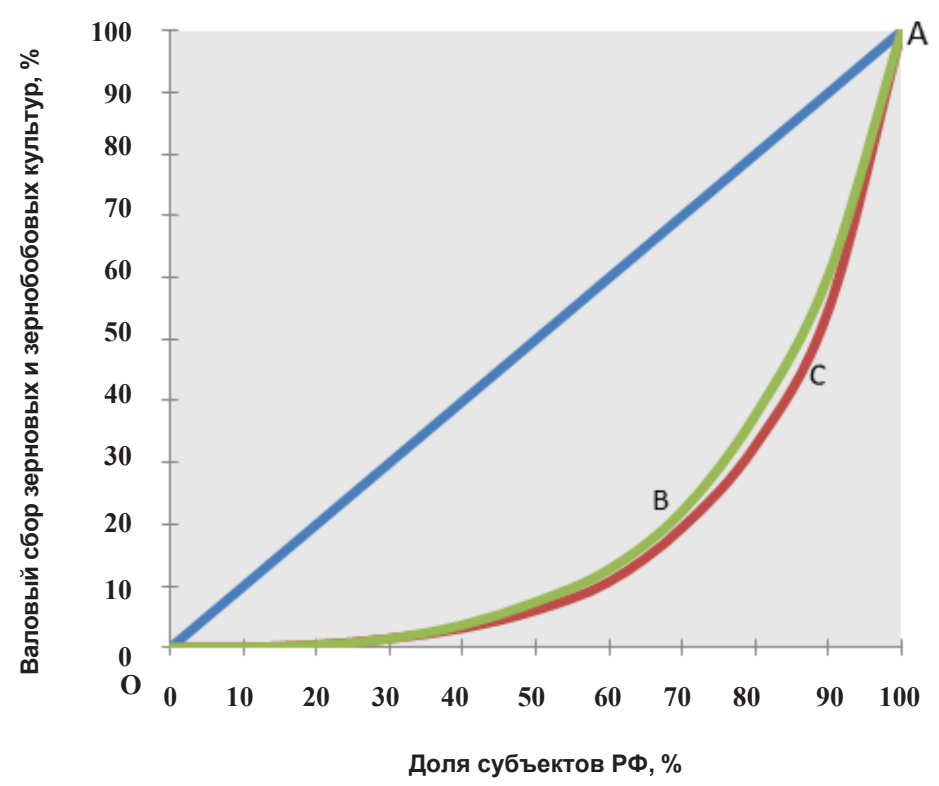

Рис. Распределение валового сбора зерновых и зернобобовых культур в хозяйствах всех категорий по группам субъектов РФ в 2008 г. и 2020 г. (источник: https://fedstat.ru). 
Таблица. Группировка субъектов РФ по объемам валового сбора зерна в расчёте на душу населения (в среднем за год в 2016-2020 гг.)*

\begin{tabular}{|c|c|c|c|c|c|c|c|}
\hline \multirow{2}{*}{$\begin{array}{c}\text { Группы регионов } \\
\text { по показателю валового } \\
\text { сбора зерна } \\
\text { в расчёте на } 1 \text { чел., кг }\end{array}$} & \multicolumn{2}{|c|}{ Субъекты РФ } & \multicolumn{2}{|c|}{ Валовой сбор } & \multicolumn{2}{|c|}{$\begin{array}{c}\text { Численность } \\
\text { населения }\end{array}$} & \multirow{2}{*}{$\begin{array}{c}\text { Средние объемы } \\
\text { валового } \\
\text { сбора зерна, } \\
\text { кг на } 1 \text { чел. }\end{array}$} \\
\hline & количество & $\begin{array}{c}\text { в \% } \\
\text { к итогу }\end{array}$ & тыс. т. & $\begin{array}{c}\text { в \% } \\
\text { к итогу }\end{array}$ & тыс. чел. & $\begin{array}{l}\text { в \% к } \\
\text { итогу }\end{array}$ & \\
\hline до 100 & 16 & 21,6 & 976,8 & 0,8 & 20061,5 & 15,9 & 49 \\
\hline от 101 до 200 & 10 & 13,5 & 2529,2 & 2,0 & 17665,3 & 14,0 & 143 \\
\hline от 201 до 500 & 12 & 16,2 & 7370,2 & 5,9 & 20490,8 & 16,3 & 360 \\
\hline от 501 до 1000 & 10 & 13,5 & 15486,3 & 12,4 & 21776,8 & 17,3 & 711 \\
\hline от 1001 до 1500 & 7 & 9,5 & 12016,4 & 9,7 & 9844,5 & 7,8 & 1221 \\
\hline от 1501 до 2000 & 8 & 10,8 & 25122,4 & 20,2 & 14461,8 & 11,5 & 1737 \\
\hline от 2001 до 3000 & 7 & 9,5 & 39970,6 & 32,1 & 15969,6 & 12,7 & 2503 \\
\hline свыше 3000 & 4 & 5,4 & 20968,1 & 16,8 & 5679,0 & 4,5 & 3692 \\
\hline Всего & 74 & 100,0 & 124440 & 100,0 & 125949,3 & 100,0 & 988 \\
\hline
\end{tabular}

*При составлении таблицы авторами использованы данные Федеральной службы государственной статистики (https://fedstat.ru/indicator/30950).

Рост спроса на зерно положительно повлиял на размещение производства по регионам страны, так как несколько снизился уровень его территориальной дифференциации. На рисунке с помощью кривой Лоренца (В.С. Немчинов, 1968) показано, что в 2020 г. относительно 2008 г. размещение производства зерновых по субъектам Федерации стало более равномерным.

Отметим, что на рисунке диагональ ОА представляет линию равновесия, кривая ОСА - распределение валового сбора зерновых и зернобобовых культур в 2008 г., а кривая ОБА - распределение валового сбора зерновых и зернобобовых культур в 2020 г.

Тем не менее количественно на $20 \%$ субъектов РФ (9 и 10 их децильные группы) в 2020 г. приходилось $62 \%$ объема валового сбора зерновых и зернобобовых культур (хотя в 2008 г. это составляло $67 \%$ ). В свою очередь, в 20 \% субъектов РФ с малыми объемами получаемых урожаев зерна (1 и 2 децильные группы) было произведено 0,5 \% от общероссийского показателя (при 0,4 \% в 2008 г.).

Данные расчёты показывают, что субъекты Федерации неоднородны по своему вкладу в формирование зернового рынка. Одни из них могут ориентироваться преимущественно на зарубежные рынки, другие - на национальный рынок России в целом, третьи - на региональные рынки, четвертые - на потребление зерна на местном рынке для текущих потребностей и кормовых целей.

Для классификации субъектов РФ по потенциальным возможностям выхода на тот или иной уровень зернового рынка воспользуемся эталонным показателем «производство одной тонны зерна в расчёте на душу населения», который был предложен академиком В.C. Немчиновым. В основу расчета им были положены нормыпотребления основныхпродуктовпитания (зерно, картофель, мясо, молоко, яйца, сахар) и потребность в зерне в рационах кормления сельскохозяйственных животных для получения необходимого количества продукции животноводства, исходя из соотношения между кормовым и продовольственным зерном, равным 4 (О.И. Павлов, О.Ю. Павлова, 2016).

По данным Росстата, зерновые и зернобобовые культуры в настоящее время возделываются в 74 субъектах РФ, группировка которых по показателям объемов валового сбора зерна в расчёте на душу населения в среднем за год в 2016-2020 гг. приведена в таблице.

При производстве зерна в 2016-2020 гг. в среднем по России, равном 851 кг на человека в год (с учетом всего населения страны), в зерносеющих регионах в целом этот показатель был близок к одной тонне (988 кг). Причем на 26 субъектов РФ, где производство превышало одну тонну, приходилось 78,8 \% всего валового сбора зерна в Российской Федерации. Данные регионы - основные поставщики зерна на национальный и зарубежные рынки, образуют в Европейской части России два сплошных ареала: юго-западный - от Курской и Орловской областей до Краснодарского и Ставропольского краев, и юго-восточный - от Рязанской, Пензенской областей и Республики Мордовия до Республики Башкортостан и Оренбургской области. В Азиатской части страны - это Алтайский край, Курганская и Омская области. 
В 38 регионах (более половины субъектов РФ), производящих менее 0,5 тонны зерна на душу населения, валовой сбор зерна суммарно был равен $8,7 \%$ от всего объема общероссийского его производства. Основу данной группы регионов составили 18 областей и республик нечерноземной зоны, 14 регионов Сибири и Дальнего Востока. Производство зерна здесь, преимущественно может быть ориентировано на реализацию на местном рынке или непосредственно в сельскохозяйственных предприятиях на корм скоту, семенные цели и др. Товаропроизводители в субъектах РФ с производством зерна от 500 до 1000 кг на душу населения вполне могут участвовать в формировании предложения на региональные зерновые рынки, а такие крупные производители данной группы, как Республика Башкортостан, Красноярский край, Новосибирская и Самарская области - стать активными участниками национального рынка.

\section{Заключение}

Рынок зерна влияет на функционирование других видов рынков и достижение сбалансированного состояния национальной продовольственной системы в целом. Растущий уровень конкуренции на мировом рынке зерна и продуктов его переработки, другие глобальные факторы вызывают необходимость постоянного изучения взаимосвязей в функционировании зернового комплекса.

В настоящее время исследования, направленные на обоснование объемов производства зерновых для достижения необходимого уровня обеспечения населения продовольствием, позволяющие усовершенствовать систему управления национальной экономикой, ее основополагающей составляющей - агропромыш- ленным комплексом, приобретают особую значимость. Государственная стратегия обеспечения населения продовольствием, одной из задач которой является продовольственная безопасность, должна быть направлена на достижение сбалансированного (идеального) состояния национальной продовольственной системы. Эта стратегия должна решать задачи не только развития собственного производства продовольствия, его хранения, переработки и внешней торговли, но и обоснованного распределения основных продуктов питания, устойчивого развития сельских территорий, вовлечения в хозяйственный оборот необрабатываемых годами земель.

\section{Литература}

1. Воронина Н.П. Правовое регулирование государственной поддержки сельскохозяйственных кооперативов в России и зарубежных странах // Вестник Университета имени О.Е. Кутафина. - 2019. - N 1 (53), https://cyberleninka.ru/article/n/pravovoe-regulirovaniegosudarstvennoy-podderzhki-selskohozyaystvennyhkooperativov-v-rossii-i-zarubezhnyh-stranah.

2. Немчинов В.С. Избранные произведения. - Т. 5: Планирование и народно-хозяйственные балансы. - М.: Наука, 1968. - 387 с.

3. Павлов О.И., Павлова О.Ю. Кривая Лоренца и математическое определение среднего класса // УЭкС, 2016. - N 12 (94), https://cyberleninka.ru/article/n/krivayalorentsa-i-matematicheskoe-opredelenie-srednego-klassa.

4. Федеральная служба государственной статистики (Росстат) https://fedstat.ru/indicator/30950 (просмотрено: 15.08.2021).

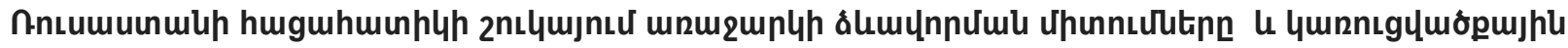 untinu2undtinn}

\section{U.ᄂ. Epnnlynu, h.R. Spnเ2lhlum}

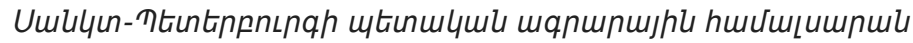

\section{U. ULtpumujulu}

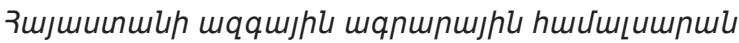

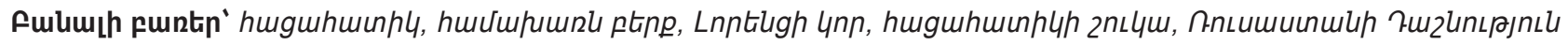

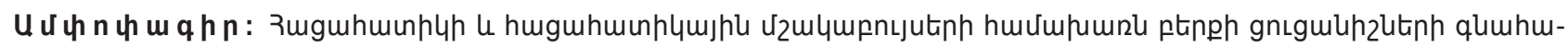

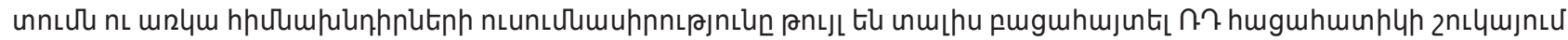

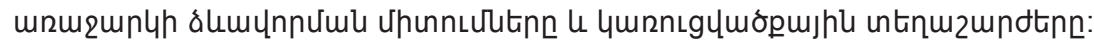

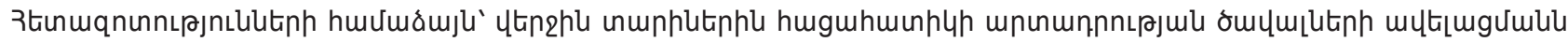

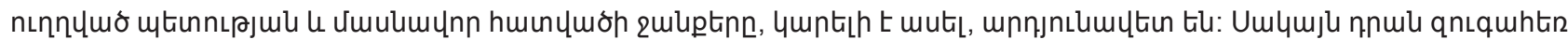

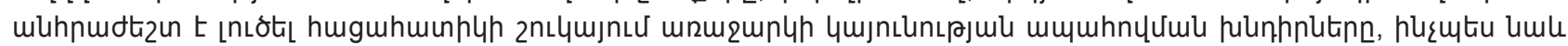

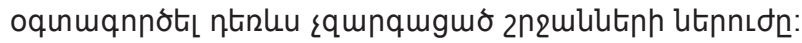


The Tendency and Structural Shifts in Supply Formation of Grain Market of the Russian Federation

S.N. Shirokov, I.R. Trushkina

Saint-Petersburg State Agrarian University

V.S. Aleksanyan

Armenian National Agrarian University

Keywords: grain, gross product, Lorenz curve, grain market, Russian Federation

A b stract. Evaluation of gross yield indicators in grain and leguminous crops and the study of current issues, on the whole, enable to disclose the supply formation tendencies and structural shifts in the grain market of the RF.

Based on the studies, it can be inferred that the efforts of state and private sectors aimed at the increase of grain production dimensions have been efficient over the past years. Nevertheless, it is also necessary to solve the problem of ensuring stable supply in the grain market, as well as to use the potential of still lagging regions in the republic.

Исследование выполнено при финансовой поддержке РФФИ и КН РА в рамках научного проекта № 20-510-05020120 (№ 20RF-054). 